\title{
PREDICTIVE EQUATIONS OF MAXIMUM OXYGEN CONSUMPTION BY SHUTTLE RUN TEST IN CHILDREN AND ADOLESCENTS: A SYSTEMATIC REVIEW
} Equações preditivas do consumo máximo de oxigênio por meio do teste shuttle run em crianças e adolescentes: uma revisão sistemática

\author{
Francisco José de Menezes Júnior ${ }^{a, *}$ (D), Íncare Correa de Jesus ${ }^{a}$ (D), Neiva Leite ${ }^{a}$ (D)
}

\section{ABSTRACT}

Objective: To systematically review the literature as for the level of evidence of predictive equations of $\mathrm{VO}_{2 \text { peak }}$ through the 20 -meter shuttle run test (20m-SRT) in children and adolescents.

Data sources: Searches were conducted independently by two researchers, according to the procedures adopted by PRISMA, in the electronic databases MEDLINE via PubMed, ScienceDirect, Web of Science, LILACS and SciELO, for articles published until September 2017 in English and Portuguese. The inclusion criteria were: original studies, abstract available, using predictive equations of $\mathrm{VO}_{2 \text { peak }}$ through $20 \mathrm{~m}-\mathrm{SRT}$, conducted with adolescents and/or children, non-athletes, and mentioning correlation analysis between predicted and measured $\mathrm{VO}_{2 \text { peak. }}$. The level of evidence of equations was based on the risk of bias of the studies using the following criteria: sample number, sample characteristics, and statistical analysis.

Data synthesis: Eighteen studies were selected, in which fifteen equations were found and analyzed. The studies had been conducted with samples composed of subjects of both sexes, aged 8 to 19 years. Equations of Léger and Matsuzaka had their level of evidence classified as high, and estimation ranged between $r=0.54-0.90$ and $r=0.65-0.90$. Equations by Ruiz, Barnett and Matsuzaka had their level of evidence classified as moderate, and estimation ranged between $r=0.75-0.96, r=0.66-0.84$ and $r=0.66-0.89$, respectively.

Conclusions: Matsuzaka's equation presented satisfactory parameters for estimates of $\mathrm{VO}_{2 \text { peak }}$ in children and adolescents. Although not explored in equations, body adiposity and pubertal stage are significantly associated with cardiorespiratory fitness in children and adolescents.

Keywords: Cardiopulmonary Exercise Test; Cardiorespiratory fitness; Adolescents; Children.

\section{RESUMO}

Objetivo: Revisar sistematicamente na literatura o nível de evidência das equações preditivas do pico de consumo de oxigênio $\left(\mathrm{VO}_{2 \text { pico }}\right)$ por meio do teste de shuttle run de 20 metros (SR-20m) em crianças e adolescentes.

Fonte de dados: As buscas foram conduzidas nas bases de dados eletrônicas Medical Literature Analysis and Retrieval System Online (MEDLINE) via PubMed, ScienceDirect, Web of Science, Literatura Latino-Americana e do Caribe em Ciências da Saúde (LILACS) e Scientific Electronic Library Online (SciELO), de agosto a setembro de 2017, nos idiomas inglês e português. Os critérios de inclusão utilizados foram: estudos originais, com resumo disponível, com equações para predição do $\mathrm{VO}_{2 \text { pico }}$ por meio do SR-20m, adolescentes e/ou crianças, não atletas e com análise correlacional do $\mathrm{VO}_{\text {2pico }}$ predito e mensurado. O nível de evidência das equações foi caracterizado com base no risco de viés dos estudos, no qual se adotou os seguintes critérios: número da amostra, características da amostra e análise estatística.

Síntese dos dados: Dezoito estudos foram selecionados, nos quais 12 equações foram encontradas e analisadas. Os estudos foram conduzidos com amostras de ambos os sexos com idades de oito a 19 anos. As equações de Léger e Matsuzaka foram classificadas com forte nível de evidência, com variação de amplitude de estimativa entre $r=0,54-0,90$ e $r=0,65-0,90$. Enquanto as equações Ruiz, Barnett e Matsuzaka foram consideradas de evidência moderada, com variação de amplitude de estimativa entre $r=0,75-0,96, r=0,66-0,84$ e $r=0,66-0,89$, respectivamente. Conclusões: A equação de Matsuzaka apresentou parâmetros satisfatórios para estimar o $\mathrm{VO}_{2 \text { pico }}$ em crianças e adolescentes. Embora não explorados em equações, a adiposidade corporal e o estágio puberal demonstram associações relevantes com a aptidão cardiorrespiratória em crianças e adolescentes.

Palavras-chave: Teste de esforço; Aptidão cardiorrespiratória; Adolescentes; Crianças.

*Corresponding author. E-mail: franciscomenezes@ufpr.br (F.J. Menezes Junior).

aniversidade Federal do Paraná, Curitiba, PR, Brazil.

Received on November 27, 2017; approved on March 25, 2018; available online on February $28,2019$. 


\section{INTRODUCTION}

Cardiorespiratory fitness (CRF) is an important health marker in children and adolescents ${ }^{1}$, as it reflects cardiopulmonary efficiency for oxygen and musculoskeletal distribution during exercise or physical activity. ${ }^{2,3}$ Studies have shown that children with low CRF tend to maintain this condition over the years, which adversely affects their functional capacity to perform daily activities and quality of life. ${ }^{4,5}$ In addition, low CRF is associated with an increase in risk factors for cardiovascular diseases and metabolic changes related to pediatric morbidity and mortality in adults. ${ }^{6,7}$

Thus, CRF analysis is a measure of health status of the child and adolescent population. ${ }^{6}$ It provides relevant information to the diagnosis and prognosis of cardiometabolic risk factors. ${ }^{6}$ Moreover, it serves as an instrument in individualized therapeutics and exercise prescription. ${ }^{8}$ Oxygen consumption $\left(\mathrm{VO}_{2}\right)$ is considered the main index to determine CRF. ${ }^{9}$ In children and adolescents, the peak of oxygen consumption $\left(\mathrm{VO}_{2 \text { peak }}\right)$ is generally used, defined as the peak of $\mathrm{VO}_{2}$ reached at the end of maximum effort period. ${ }^{9}$

$\mathrm{VO}_{2 \text { peak }}$ can be measured by direct methods by ergospirometric analysis in maximum tests conducted in laboratory with different ergometers or in field, by sport activity simulation..$^{10,8}$ From direct testings, authors have proposed equations that assess $\mathrm{VO}_{\text {2peak }}$ by indirect methods, which can be performed in maximum or submaximal tests, thus increasing practicality and reducing the costs of evaluations. ${ }^{11}$

In epidemiological studies, indirect field tests are mostly indicated because they usually require low cost, short time of execution and ease of simultaneous application in a larger number of individuals. ${ }^{12,13}$ The 20 -meter shuttle run test $(20 \mathrm{~m}$ SRT), conceived and described by Léger et al. ${ }^{14}$ for the adult population, is one of the field protocols most used in children and adolescents. ${ }^{6} 20 \mathrm{~m}$-SRT is considered a simple method, as it requires few equipment, can be performed in space-limited environments, and allows to assess several individuals at the same time, which can increase participants' motivation. ${ }^{2,6} \mathrm{~A}$ systematic review including about 319,000 children and adolescents from 32 countries reported the performance achieved at the $20 \mathrm{~m}$-SRT as directly related to health indicators in children and adolescents. ${ }^{5}$

In the last decades, the $20 \mathrm{~m}$-SRT was included in several batches of physical fitness tests such as EUROFIT and FITNESSGRAM, ${ }^{6}$ resulting in the need to improve $\mathrm{VO}_{\text {2peak }}$ predictive equations through this test for the child and adolescent population. ${ }^{15,16}$ Equations were therefore developed using mathematical regression models or artificial neural networks, and including biological characteristics such as age, sex, body mass and performance in the test. ${ }^{17,18}$
On the other hand, prediction of $\mathrm{VO}_{2 \text { peak }}$ by equations may vary in measurements depending on the characteristics of the sample, especially age group, stage of sexual maturation, gender, and body composition. ${ }^{16,18}$ So, in order for an equation to be considered appropriate, it must have adequate validity, that is, produce little variation range between estimate values. ${ }^{19}$ Batista et al. ${ }^{19}$ pointed out the relevance of analyzing the level of evidence of equations developed to estimate $\mathrm{VO}_{2 \text { peak }}$ in children and adolescents, and contributed to this review in a more careful and orderly manner.

Therefore, it is not clear which equation establishes better accuracy for estimates based on the different characteristics of the child and adolescent population, or which variables are important to predict $\mathrm{VO}_{2 \text { peak }}$, because so far, the findings of different studies have not been systematically analyzed. Thus, the objective of this study was to systematically review the literature to assess the level of evidence of equations intended to predict $\mathrm{VO}_{2 \text { peak }}$ through the $20 \mathrm{~m}$-SRT in children and adolescents.

\section{METHOD}

This work was conducted in compliance with recommendations by the Preferred Reporting Items for Systematic Review and Meta-analyzes: the PRISMA statement, ${ }^{20}$ from August to September 2017.

Five online databases were selected according to the field of knowledge and scientific relevance worldwide: Medical Literature Analysis and Retrieval System Online (MEDLINE) via PubMed, ScienceDirect, Web of Science, Latin American and Caribbean Literature in Health Sciences (LILACS), and Scientific Electronic Library Online (SciELO). We also searched the reference lists of articles selected that were related to the topic.

The search strategies were defined after identification and selection of search descriptors, based on DECS (BIREME health sciences descriptors) and MESH (Medical Subject Headings controlled vocabulary used for indexing articles for PubMed). In this way, the following keywords were chosen in English and Portuguese: Cardiopulmonary Exercise Test, Oxygen consumption, Children and Adolescents. The keywords were combined using "AND" and/or "Boolean" terms and the period of study publication was set until September 2017.

After using the selected descriptors, the studies in duplicity were discarded and the inclusion (1,2 and 3) and non-inclusion (4, 5 and 6) criteria were applied to screened studies, upon reading of the headings and abstracts:

- Original studies with transversal or longitudinal design, or clinical trial. 
- Abstract accessible in the searched databases.

- Studies using equations for $\mathrm{VO}_{\text {2peak }}$ prediction for the 20m-SRT.

- Samples with adults and/or elderly people.

- Studies conducted with athletes.

- Absence of correlation analysis between $\mathrm{VO}_{2 \text { peak }}$ predicted by indirect method and $\mathrm{VO}_{2 \text { peak }}$ measured by direct method.

After this step, articles classified as eligible were read and analyzed in full; studies were excluded for several reasons: sample presenting a diagnosed pathology, sample made up of adults and adolescents who were analyzed together, adapted shuttle run protocol, no direct measurement of $\mathrm{VO}_{2 \text { peak }}$, no correlation analysis, and/or no $\mathrm{VO}_{2 \text { peak }}$ prediction.

The criteria for bias risk assessment were adapted by Batista et al. ${ }^{19}$ and three parameters were observed: number of participants, sample description and statistical analysis. In order to measure, each parameter was assigned a score of 0 to 2 points.

As for the number of participants, the studies were classified as "0", when the sample had less than 10 participants; "1", between 11 and 50 participants; or " 2 " more than 51 participants. Age, sex, health status, physical fitness level, pubertal status, body composition, physical activity level and ethnicity were considered when analyzing sample characteristics. Based on these aspects, the studies were scored as " 0 " when less than four characteristics were described; "1" for four characteristics; or "2" for more than four features. The studies were classified as " 0 " when presenting no regression analysis or error measures; " 1 ", when presenting regression analysis and/or error measures; and " 2 " when more than three statistical analyzes were present, or Bland-Altman plot and/or analysis of variance (ANOVA) of repeated measurements. The studies were all categorized according to the scores received: high risk of bias (0-2 points), moderate risk of bias ( 3 and 4 points) and low risk of bias ( 5 and 6 points).

Subsequently, the validity of the identified equations was assessed based on the evidence-level criteria expressed by CastroPiñero et al.: ${ }^{21}$

- Strong evidence: equations validated by three or more studies with low risk of bias.

- Moderate evidence: equations validated by two studies with low risk of bias.

- Limited evidence: equations validated by studies with high risk of bias, inconsistent results among several studies, regardless of risk of bias, or the results of a single study.
Some characteristics of the samples were highlighted in the studies, such as age, gender and number of subjects. The values of correlation coefficient $(r)$ and standard estimation error (SEE) in $\mathrm{mL} / \mathrm{kg}$.min were extracted when available. Estimate range variation $(\Delta \mathrm{ER})$ of each equation was determined by the description from the lowest to the highest correlation coefficient obtained by the equation between the studies. To facilitate identification, we chose to name the equations with the name of the first author of the study in which it was validated. When one author had identified two or more equations in a single study, each equation was accompanied by (a), (b) or (c).

The steps of the process of research, selection, analysis, application of bias risk parameters, and data extraction were independently performed by two researchers (FJMJ and ICJ), and, in case of disagreement, a third researcher (NL) was asked to decide on divergent points.

\section{RESULTS}

In total, 2,125 studies were found using the combination of selected descriptors, but 194 were discarded for being duplicates. Afterwards, the inclusion and non-inclusion criteria were applied and 64 studies were considered eligible in full, ending the selection with 14 articles for qualitative synthesis. In addition, four studies relating to the theme identified in other reference lists of articles selected were included, so 18 studies were selected. The process of studies selection is outlined in Figure 1.

Following criteria adapted by Batista et al., ${ }^{19}$ nine studies were classified as low risk of bias, ${ }^{17,21-27,36}$ and other nine as moderate risk of bias. ${ }^{15,16,18,29-35}$ The details of risk assessment criteria are shown in Table 1.

The samples of studies selected had subjects aging 8 to 19 years, most of them with nutritional status classified as eutrophic, except for two overweight studies. ${ }^{22,36}$

We identified studies that aimed to develop equations using variables in mathematical regression models, ${ }^{18,23,25,27,29,31,33,35,36}$ and artificial neural networks. ${ }^{17,25}$ The variables used in equations were gender, ${ }^{17,18,23,25,31,33,35,36}$ age, ${ }^{17,23,25,27,29,31,33,36}$ body mass index (BMI), ${ }^{18,23,25,33,35,37}$ body mass, ${ }^{17,25,31,33}$ stature $^{17,25}$ and triceps skinfold ${ }^{31}$, besides performance in $20 \mathrm{~m}$-SRT (final speed in $\mathrm{km} / \mathrm{h},{ }^{23,29,31,36}$ number of laps, ${ }^{18,23,28,33,35}$ number of stages ${ }^{17,25}$ and number of laps squared. ${ }^{18}$ The equations identified had their characteristics detailed in Tables 2 and 3.

In addition, some studies had a cross-validation of equations as objective: Léger, ${ }^{15,17,18,22,24-26,28,30-34}$ Barnett (a) ${ }^{15,18,24,26}$ Barnett (b), ${ }^{15,18,25,28}$ Barnett (c), ${ }^{24}$ Matsuzaka (a), ${ }^{15,18,24,26}$ Matsuzaka (b), ${ }^{18,24}$ Mahar (a), ${ }^{18,26,34}$ Mahar (b), ${ }^{18,27,34}$ Mahar (squared), ${ }^{27,34}$ Burns $^{16}$ 
Studies identified in search on

PubMed, LILACS, ScienceDirect,

SciELO and Web of Science

$(n=2,125)$

Manual inclusion of studies identified from other sources $(n=4)$

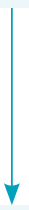

$$
\downarrow
$$

Duplicates excluded $(n=194)$
Studies chosen based on title and abstract reading $(n=1,935)$

Full-text studies assessed for eligibility $(n=64)$
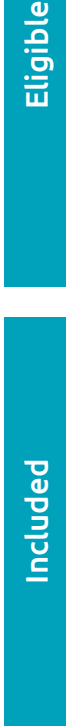

Articles included in a qualitative synthesis $(n=18)$
Studies excluded by inclusion or non-inclusion criteria: not original articles, no abstract available, no equations for $\mathrm{VO}_{2 \text { peak }}$ prediction in 20m-SRT, adults and/or elderly, athletes in the sample, and no predicted versus measured $\mathrm{VO}_{2 \text { peak }}$ correlation analysis $(n=1,871)$
Complete studies excluded by eligibility criteria: pathology diagnosed, adapted shuttle run protocol, no direct measurement of $\mathrm{VO}_{2 \text { peak, }}$ no correlation analysis and/or no $\mathrm{VO}_{2 \text { peak }}$ prediction

20m-SRT: 20-meter shuttle run test; $\mathrm{VO}_{\text {2peak: }}$ : peak of oxygen consumption.

Figure 1 PRISMA flowchart. 
and Fernhall. ${ }^{23,32}$ Among all equations, two had a strong level of evidence, ${ }^{23,29}$ three had moderate level ${ }^{17,23,31}$ and seven had limited level of evidence. ${ }^{18,27,31,33,35}$

Among the equations with strong level of evidence, Léger ${ }^{29}$ was the most commonly applied in cross-validations, however it shows considerable $\Delta \mathrm{ER}$ and lower values of estimates for girls. The equation by Matsuzaka (a ${ }^{23}$ is considered strong-evidence, and able to generate estimates with lower $\Delta \mathrm{ER}$ and higher correlation values for boys.

As for moderate evidence, the equation by Ruiz ${ }^{16}$ showed a low $\Delta \mathrm{ER}$, while Barnett's $(\mathrm{a})^{31}$ and Matsuzaka's $(\mathrm{b})^{23}$ resulted in high association values, but low $\Delta \mathrm{ER}$, respectively. In addition, Barnett's equation $(\mathrm{a})^{31}$ had higher correlation values for girls.

Finally, the equations by Barnett (b), ${ }^{31}$ Barnett (c), ${ }^{31}$ Mahar (a), ${ }^{33}$ Mahar (b), ${ }^{33}$ Mahar (squared), ${ }^{18}$ Silva (a), ${ }^{25}$ Silva (b), ${ }^{25}$ Burns,${ }^{27}$ Fernhall ${ }^{135}$ and Quinart ${ }^{36}$ were classified as limited evidence. The level of evidence of equations and respective $\Delta \mathrm{ER}$ are listed in Table 4.

\section{DISCUSSION}

This systematic review gathered 18 studies in which fifteen equations were identified. Among these, different variables were employed, including sample characteristics and performance in $20 \mathrm{~m}$-SRT. Two equations had a strong level of evidence, ${ }^{23,29}$ three were classified as moderate evidence ${ }^{17,23,31}$, and nine as limited evidence. ${ }^{18,25,27,31,33,35}$ Our findings show that Matsuzaka's $(a)^{23}$ equation tends to have higher predictive reliability and a high level of evidence for both genders and may be a potential equation to estimate the $\mathrm{VO}_{2 \text { peak }}$ in eutrophic boys.

As previously presented, children and adolescents with high $\mathrm{VO}_{2 \text { peak }}$ levels tend to have risk factors related to cardiovascular diseases, obesity and the metabolic syndrome reduced. ${ }^{5,7}$ Thus, the accuracy of equations to estimate $\mathrm{VO}_{\text {2peak }}$ is relevant, since it provides valuable information for the diagnosis and prognosis of cardiometabolic risk factors. ${ }^{6,8}$ Access to a practical and inexpensive method is important; the $20 \mathrm{~m}$-SRT has fulfilled this requirement with strong level of evidence. ${ }^{6,19}$ This test requires cheap resources and infrastructure that is easily accessible in schools, clubs and academies. In addition, it can be considered practical and efficient, as it allows the evaluation of several people at the same time. ${ }^{6}$

According to our findings, Léger's equation ${ }^{29}$ was primary to estimate $\mathrm{VO}_{\text {2peak }}$ in children and adolescents in the literature. This equation, which uses age and performance in $20 \mathrm{~m}$-SRT

Table 1 Classification of bias risk of each study.

\begin{tabular}{|c|c|c|c|c|}
\hline Studies & $\begin{array}{l}\text { Number } \\
\text { of subjects }\end{array}$ & $\begin{array}{c}\text { Sample } \\
\text { characteristics }\end{array}$ & $\begin{array}{c}\text { Statistical } \\
\text { analysis }\end{array}$ & Bias risk \\
\hline Léger et al..29 & 2 & 0 & 1 & Moderate \\
\hline Liu et al. ${ }^{30}$ & 1 & 2 & 1 & Moderate \\
\hline Barnett et al. ${ }^{31}$ & 2 & 1 & 1 & Moderate \\
\hline Pitetti et al. ${ }^{32}$ & 2 & 1 & 1 & Moderate \\
\hline Suminski et al. ${ }^{22}$ & 2 & 2 & 1 & Low \\
\hline Matsuzaka et al..23 & 2 & 2 & 2 & Low \\
\hline Mahar et al..33 & 2 & 1 & 1 & Moderate \\
\hline Ruiz et al. ${ }^{17}$ & 2 & 1 & 2 & Low \\
\hline Ruiz et al. ${ }^{15}$ & 1 & 1 & 2 & Moderate \\
\hline Boiarskaia et al. ${ }^{34}$ & 2 & 1 & 0 & Moderate \\
\hline Mahar et al. ${ }^{18}$ & 2 & 1 & 1 & Moderate \\
\hline Melo et al..24 & 2 & 2 & 1 & Low \\
\hline Silva et al. ${ }^{25}$ & 2 & 2 & 2 & Low \\
\hline Batista et al. ${ }^{26}$ & 2 & 2 & 2 & Low \\
\hline Quinart et al. ${ }^{37}$ & 1 & 2 & 2 & Low \\
\hline Burns et al. ${ }^{27}$ & 2 & 1 & 2 & Low \\
\hline Ernesto et al..$^{28}$ & 2 & 1 & 2 & Low \\
\hline Sain-Maurice et al. ${ }^{16}$ & 2 & 1 & 1 & Moderate \\
\hline
\end{tabular}

5 or 6 : low bias risk; 3 or 4: moderate risk of bias; 1 or 2 : high risk of bias. 
as variables, was more popular in studies and presented strong evidence. However, it presents a considerable $\Delta$ ER between correlation values, being frequently inferior to $r=0.60 .{ }^{15,18,22,32-}$ ${ }^{34}$ This variation can be explained by differences in gender between subjects in the sample. Although Léger et al. ${ }^{29}$ found no significant predictive value for gender, other studies demonstrate a strong association between this component and cardiorespiratory fitness in children and adolescents. ${ }^{18,32}$

On the other hand, the Matsuzaka's equation $(a)^{23}$, with strong evidence, obtained values of estimate validity with lower

Table 2 Equations for prediction of maximal oxygen consumption upon the 20-meter shuttle run test in children and adolescents (equations by Léger et al., Ruiz et al., Barnett et al.)

\begin{tabular}{|c|c|c|c|c|c|c|}
\hline \multirow[t]{2}{*}{ Equation } & \multirow[t]{2}{*}{ Study } & \multirow{2}{*}{$\begin{array}{l}\text { (n) age } \\
\text { range }\end{array}$} & \multicolumn{3}{|c|}{$\begin{array}{c}\mathrm{r}(\mathrm{SEE} \mathrm{mL} / \mathrm{kg} \cdot \mathrm{min}) \\
\text { (predicted versus measured } \mathrm{VO}_{2} \text { ) }\end{array}$} & \multirow{2}{*}{$\begin{array}{l}\text { Variables } \\
\text { in equation }\end{array}$} \\
\hline & & & $+0^{\pi}$ & $\pi$ & 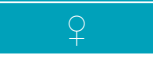 & \\
\hline \multirow{16}{*}{$\begin{array}{l}\text { Léger } \\
\text { et al. }{ }^{29}\end{array}$} & Léger et al..29 & (188) 8-19 & $0.71(5.9)$ & & & \multirow{16}{*}{ Age; final speed } \\
\hline & Liu et al. ${ }^{30}$ & (62) $12-15$ & $0.72(5.2)$ & & & \\
\hline & Barnett et al. ${ }^{31}$ & (55) 12-17 & $0.72(5.4)$ & & & \\
\hline & Pitetti et al. ${ }^{32}$ & (61) 8-15 & 0.57 & & & \\
\hline & Suminski et al. ${ }^{22}$ & (125) 10-12 & $0.62(3.9)$ & $0.58(4.7)$ & $0.55(3.1)$ & \\
\hline & Suminski et al.22 & (81) $10-12$ & $0.54(4.2)$ & & & \\
\hline & Suminski et al.22* & (44) $10-12$ & $0.81(3.2)$ & & & \\
\hline & Mahar et al. ${ }^{33}$ & (135) $12-14$ & $0.54(6.6)$ & & & \\
\hline & Ruiz et al. ${ }^{17}$ & (193) 13-19 & $0.90(4.2)$ & & & \\
\hline & Ruiz et al. ${ }^{15}$ & (48) 13-19 & $0.58(6.5)$ & & & \\
\hline & Boiarskaia et al. ${ }^{34}$ & (135) 12-14 & 0.54 & 0.46 & 0.39 & \\
\hline & Mahar et al. ${ }^{18}$ & (244) 10-16 & $0.58(7.6)$ & & & \\
\hline & Melo et al..$^{24}$ & (90) 8-10 & 0.88 & & & \\
\hline & Silva et al. ${ }^{25}$ & (114) 10-18 & $0.67(7.1)$ & & & \\
\hline & Batista et al. ${ }^{26}$ & (115) 11-13 & $0.60(7.5)$ & $0.60(7.7)$ & $0.49(6.4)$ & \\
\hline & Ernesto et al. ${ }^{28}$ & (90) 13-17 & & $0.76(4.1)$ & $0.53(2.4)$ & \\
\hline \multirow{3}{*}{$\begin{array}{l}\text { Ruiz } \\
\text { et al. }{ }^{17}\end{array}$} & Ruiz et al. ${ }^{17}$ & (193) 13-19 & $0.96(2.8)$ & & & \multirow{3}{*}{$\begin{array}{l}\text { Gender; age; BM; } \\
\text { stature; stage }\end{array}$} \\
\hline & Ruiz et al. ${ }^{15}$ & (48) 13-19 & $0.75(5.3)$ & & & \\
\hline & Silva et al. ${ }^{25}$ & (114) 10-18 & $0.86(6.2)$ & & & \\
\hline \multirow{5}{*}{$\begin{array}{l}\text { Barnett } \\
\text { et al. } .^{31} \text { (a) }\end{array}$} & Barnett et al. ${ }^{31}$ & (55) 12-17 & $0.84(3.7)$ & & & \multirow{5}{*}{ Gender; BM; final speed } \\
\hline & Ruiz et al. ${ }^{15}$ & (48) 13-19 & $0.75(5.3)$ & & & \\
\hline & Mahar et al. ${ }^{18}$ & (244) 10-16 & $0.66(7.0)$ & & & \\
\hline & Melo et al., ${ }^{24}$ & (90) 8-10 & 0.68 & & & \\
\hline & Batista et al..26 & (115) 11-13 & $0.79(5.81)$ & $0.77(6.0)$ & $0.72(5.1)$ & \\
\hline \multirow{5}{*}{$\begin{array}{l}\text { Barnett } \\
\text { et al. } .^{31} \text { (b) }\end{array}$} & Barnett et al. ${ }^{31}$ & (55) 12-17 & $0.82(4.0)$ & & & \multirow{5}{*}{ Gender; age; final speed } \\
\hline & Ruiz et al. ${ }^{15}$ & (48) 13-19 & $0.72(5.6)$ & & & \\
\hline & Mahar et al. ${ }^{18}$ & (244) 10-16 & $0.64(7.2)$ & & & \\
\hline & Silva et al. ${ }^{25}$ & (114) 10-18 & $0.71(6.8)$ & & & \\
\hline & Ernesto et al. ${ }^{28}$ & (90) 13-17 & & $0.76(4.1)$ & $0.66(4.2)$ & \\
\hline \multirow{2}{*}{$\begin{array}{l}\text { Barnett } \\
\text { et al. } .^{31}(\mathrm{c})\end{array}$} & Barnett et al. ${ }^{31}$ & (55) $12-17$ & $0.85(3.7)$ & & & \multirow{2}{*}{$\begin{array}{l}\text { Gender; triceps skinfold; } \\
\text { final speed }\end{array}$} \\
\hline & Melo et al. ${ }^{24}$ & (90) 8-10 & 0.62 & & & \\
\hline
\end{tabular}

n: sample size; r: correlation coefficient; SEE: standard estimate error; $\mathrm{VO}_{2}$ : oxygen consumption; o⿱ : male; $\widehat{\partial}$ : female; *overweight; BM: body mass; 
$\Delta \mathrm{ER}$. The authors ${ }^{23}$ included gender, age, BMI and 20m-SRT performance in the equation, that is, theirs was the first study to include BMI in prediction equations. This equation can be considered the one with greater estimation precision.

On the other hand, although the equations by Ruiz, ${ }^{17}$ Barnett (a) ${ }^{31}$ and Matsuzaka (b) ${ }^{23}$ were classified with moderate level of evidence, they showed relevant estimates of validity. In particular, Ruizs ${ }^{17}$ equation presented the lowest $\Delta \mathrm{ER}$ among the estimation results. In addition, it matched
Matsuzaka's $(a)^{23}$, taking the greater number of characteristics of the sample included into account (sex, age, body mass, height and $20 \mathrm{~m}$-SRT performance). This equation was evaluated by a few studies, but seems to be a promising tool that should be better studied.

When considering only studies with low risk of bias, findings become more evident. Léger's equation ${ }^{29}$ continues to present higher $\Delta \mathrm{ER}$ compared to Matsuzaka’s (a) ${ }^{23}$, among equations with strong evidence; Ruiz ${ }^{17}$ obtained higher correlation

Table 3 Equations for prediction of maximal oxygen consumption upon the $20 \mathrm{~m}$-SRT test in children and adolescents (Matsuzaka et al., Mahar et al., Silva et al., Burns et al., Fernhall et al., And Quinart et al.)

\begin{tabular}{|c|c|c|c|c|c|c|}
\hline \multirow[t]{2}{*}{ Equation } & \multirow[t]{2}{*}{ Study } & \multirow{2}{*}{$\begin{array}{l}\text { (n) age } \\
\text { range }\end{array}$} & \multicolumn{3}{|c|}{$\begin{array}{c}r(\mathrm{SEE} \mathrm{mL/kg} \cdot \mathrm{min}) \\
\text { (predicted versus measured } \mathrm{VO}_{2} \text { ) }\end{array}$} & \multirow{2}{*}{$\begin{array}{l}\text { Variables } \\
\text { in equation }\end{array}$} \\
\hline & & & $90^{\pi}$ & $\overline{0}$ & $q$ & \\
\hline \multirow{5}{*}{$\begin{array}{l}\text { Matsuzaka } \\
\text { et al..23 (a) }\end{array}$} & Matsuzaka et al..$^{23}$ & (132) 8-17 & $0.90(3.3)$ & & & \multirow{5}{*}{$\begin{array}{l}\text { Gender; age; BMl; } \\
\quad \text { final speed }\end{array}$} \\
\hline & Ruiz et al. ${ }^{15}$ & (48) 13-19 & $0.73(5.5)$ & & & \\
\hline & Mahar et al. ${ }^{18}$ & (244) 10-16 & $0.65(7.1)$ & & & \\
\hline & Melo et al. ${ }^{24}$ & (90) 8-10 & 0.72 & & & \\
\hline & Batista et al. ${ }^{26}$ & (115) 11-13 & $0.77(5.9)$ & $0.80(5.8)$ & $0.69(5.3)$ & \\
\hline \multirow{3}{*}{$\begin{array}{l}\text { Matsuzaka } \\
\text { et al.23 (b) }\end{array}$} & Matsuzaka et al. ${ }^{23}$ & (132) 8-17 & $0.89(3.4)$ & & & \multirow{3}{*}{ Gender; age; BMl; laps } \\
\hline & Mahar et al. ${ }^{18}$ & (244) 10-16 & $0.66(7.0)$ & & & \\
\hline & Melo et al. ${ }^{24}$ & (90) 8-10 & 0.80 & & & \\
\hline \multirow{4}{*}{$\begin{array}{l}\text { Mahar } \\
\text { et al. } .^{33} \text { (a) }\end{array}$} & Mahar et al. ${ }^{33}$ & (135) 12-14 & $0.64(6.44)$ & & & \multirow{4}{*}{ Gender; laps; BM } \\
\hline & Boiarskaia et al. ${ }^{34}$ & (135) 13 & 0.57 & 0.45 & 0.39 & \\
\hline & Mahar et al. ${ }^{18}$ & (244) 10-16 & $0.66(6.99)$ & & & \\
\hline & Batista et al. ${ }^{26}$ & (115) 11-13 & $0.80(5.69)$ & $0.77(6.11)$ & $0.71(5.2)$ & \\
\hline \multirow{4}{*}{$\begin{array}{l}\text { Mahar } \\
\text { et al. } .^{33}(b)\end{array}$} & Mahar et al. ${ }^{33}$ & (135) $12-14$ & $0.64(6.4)$ & & & \multirow{4}{*}{ Gender; age; BMl; laps } \\
\hline & Boiarskaia et al. ${ }^{34}$ & (135) 13 & 0.65 & 0.56 & 0.51 & \\
\hline & Mahar et al. ${ }^{18}$ & (244) 10-16 & $0.71(6.6)$ & & & \\
\hline & Burns et al..27 & (90) 13-16 & 0.78 & & & \\
\hline \multirow{3}{*}{$\begin{array}{l}\text { Mahar } \\
\text { et al.18 } \\
\text { (quadrática) }\end{array}$} & Boiarskaia et al. ${ }^{34}$ & (135) 13 & 0.67 & 0.62 & 0.52 & \multirow{3}{*}{ Gender; BMl; laps; laps² } \\
\hline & Mahar et al. ${ }^{18}$ & (244) 10-16 & $0.73(6.3)$ & & & \\
\hline & Burns et al. ${ }^{27}$ & (90) 13-16 & 0.74 & & & \\
\hline $\begin{array}{l}\text { Silva } \\
\text { et al. } .^{25} \text { (a) }\end{array}$ & Silva et al. ${ }^{25}$ & (114) $10-18$ & $0.80(5.7)$ & & & Gender; BMI; Stage \\
\hline $\begin{array}{l}\text { Silva } \\
\text { et al..25 (b) }\end{array}$ & Silva et al. ${ }^{25}$ & (114) $10-18$ & $0.86(5.0)$ & & & $\begin{array}{c}\text { Gender; age; BM; stature; } \\
\text { BMl; stage }\end{array}$ \\
\hline \multirow{2}{*}{$\begin{array}{l}\text { Burns } \\
\text { et al. }{ }^{27}\end{array}$} & Burns et al. ${ }^{27}$ & (90) $13-16$ & 0.77 & & & \multirow{2}{*}{ Age; laps } \\
\hline & Saint-Maurice et al. ${ }^{16}$ & (310) 10-18 & & 0.36 & 0.42 & \\
\hline \multirow{2}{*}{$\begin{array}{l}\text { Fernhall } \\
\text { et al. }{ }^{35}\end{array}$} & Pitetti et al.32 & (51) 8-15 & 0.66 & & & \multirow{2}{*}{ Gender; BMI; laps } \\
\hline & Melo et al. ${ }^{24}$ & (90) 8-10 & 0.56 & & & \\
\hline $\begin{array}{l}\text { Quinart } \\
\text { et al. }{ }^{36}\end{array}$ & Quinart et al.37* & (30) 12-17 & 0.77 & & & $\begin{array}{l}\text { Gender; age; BMl; } \\
\quad \text { final speed }\end{array}$ \\
\hline
\end{tabular}

n: sample size; r: correlation coefficient; SEE: standard estimate error; $\mathrm{VO}_{2}$ : oxygen consumption; o : male; đ: female; *overweight; BMI: body mass index; laps: number of laps; laps²: number of laps squared; MC: body mass. 
values and lower $\Delta \mathrm{ER}$, in comparison to the other equations of moderate evidence.

When analyzing data by gender in samples, only the Léger' ${ }^{29}$ equation reached strong evidence, despite having low correlation values and high $\Delta \mathrm{ER}$, showing underestimation of $\mathrm{VO}_{2 \text { peak }}$ prediction for females and males. Therefore, it was not possible to define the validity of the specific equations by gender, since few studies have provided isolated correlational information and analysis with this variable. Despite this, Barnett's (a $)^{31}$ may be a potential equation to estimate $\mathrm{VO}_{2 \text { peak }}$ in girls and Matsuzaka's (a) ${ }^{23}$ in boys, since they were shown to have higher correlational values for the respective groups.

Among equations with strong and moderate level of evidence, the Matsuzaka's (a), ${ }^{23}$ Matsuzaka's $(b)^{23}$ and Ruiz's ${ }^{17}$ equations were the ones that used the largest number of variables from the sample and obtained a lower $\Delta \mathrm{ER}$ with high correlation values. Léger ${ }^{29}$ and Barnett $(a)^{31}$ inserted fewer variables and found higher $\Delta \mathrm{ER}$ values. The use of more than one characteristic of the sample, such as gender, body mass, stature or $\mathrm{BMI}$, in equations tends to result in higher values of association between predicted and measured $\mathrm{VO}_{2 \text { peak }}$. This trend was also noted in other studies. ${ }^{37,38}$ From this point of view, moderate associations between $\mathrm{VO}_{2 \text { peak }}$ and BMI, body mass and gender were identified. . $5,32,33^{2}$
According to Saint-Maurice et al., ${ }^{38}$ BMI tends to have a larger influence on CRF in children and adolescents, which can explain 30 to $34 \%$ of the variance between $\mathrm{VO}_{2 \text { peak }}$ estimates found with predictive equations. In this perspective, equations that do not take BMI into account tend to overestimate the CRF of individuals in high nutritional status. ${ }^{38}$

Although not yet explored in prediction equations, the body fat percentage shows a significant association with CRF in both children and adolescents. ${ }^{39}$ Correlational values of $\mathrm{r}=-0.60$ for both genders, $r=-0.48$ to $-0,53$ for boys and $r=-0.24$ to -0.40 for girls evidence this variable as a strong predictor for males and moderate predictor for females. ${ }^{27,40,41}$

Although chronological age has often been used to characterize physical fitness profile, the different stages of sexual maturation tend to relate to different physical fitness characteristics in children and adolescents. ${ }^{42,43}$ Girls, specifically, demonstrate significant differences in CRF in different stages of sexual maturation, often presenting decreased $\mathrm{VO}_{2 \text { peak }}$ as their stages of sexual maturation progress. ${ }^{44}$ However, this variable has not yet been tested in prediction equations.

In addition, children and adolescents of different economic classes, sedentary behavior profiles and habitual physical activity levels may present differences as to health-related parameters. ${ }^{40,44,45}$ However, information about the use of these variables

Table 4 Classification of level of evidence and estimate range variation of the equations

\begin{tabular}{|c|c|c|c|c|c|}
\hline Equations & $\begin{array}{l}\text { Low risk of } \\
\text { bias }\end{array}$ & $\begin{array}{c}\text { Moderate risk } \\
\text { of bias }\end{array}$ & $\begin{array}{l}\text { Level of } \\
\text { evidence }\end{array}$ & $\begin{array}{c}\Delta E R \\
\text { All studies }\end{array}$ & $\begin{array}{c}\Delta E R \\
\text { Studies with } \\
\text { low risk of bias }\end{array}$ \\
\hline Léger et al. ${ }^{29}$ & 5 & 9 & Strong & $r=0.54-0.90$ & $r=0.54-0.90$ \\
\hline Ruiz et al. ${ }^{17}$ & 2 & 1 & Moderate & $r=0.75-0.96$ & $r=0.86-0.96$ \\
\hline Barnett et al. ${ }^{31}$ (a) & 2 & 3 & Moderate & $r=0.66-0.84$ & $r=0.68-0.79$ \\
\hline Barnett et al. ${ }^{31}(b)$ & 2 & 3 & Limited & $r=0.64-0.82$ & $\Gamma=0.71$ \\
\hline Barnett et al. ${ }^{31}(\mathrm{c})$ & 1 & 1 & Limited & $r=0.62-0.85$ & $r=0.62$ \\
\hline Matsuzaka et al. ${ }^{23}$ (a) & 3 & 2 & Strong & $r=0.65-0.90$ & $\Gamma=0.72-0.90$ \\
\hline Matsuzaka et al. ${ }^{23}(\mathrm{~b})$ & 2 & 1 & Moderate & $r=0.66-0.89$ & $r=0.80-0.89$ \\
\hline Mahar et al. ${ }^{33}(a)$ & 1 & 3 & Limited & $r=0.57-0.80$ & $\Gamma=0.80$ \\
\hline Mahar et al..$^{33}(b)$ & 1 & 3 & Limited & $\Gamma=0.64-0.78$ & $\Gamma=0.78$ \\
\hline Mahar et al. ${ }^{18}$ (quadrática) & 1 & 2 & Limited & $\Gamma=0.67-0.74$ & $\Gamma=0.74$ \\
\hline Silva et al. ${ }^{25}$ (a) & 1 & 0 & Limited & $r=0.80$ & $\Gamma=0.80$ \\
\hline Silva et al. ${ }^{25}(\mathrm{~b})$ & 1 & 0 & Limited & $r=0.86$ & $r=0.86$ \\
\hline Burns et al. ${ }^{27}$ & 1 & 1 & Limited & $\ulcorner=0.77$ & $\ulcorner=0.77$ \\
\hline Fernhall et al. ${ }^{35}$ & 1 & 1 & Limited & $r=0.56-0.66$ & $r=0.56$ \\
\hline Quinart et al. ${ }^{36}$ & 1 & 0 & Limited & $\Gamma=0.77$ & $\Gamma=0.77$ \\
\hline
\end{tabular}

$\triangle E R$ : estimate range variation; strong evidence: more than three studies with low risk of bias; moderate evidence: two studies with low risk of bias; limited evidence: several studies with high risk of bias, wide range of variation or only one study. 
to predict $\mathrm{VO}_{\text {2peak }}$ in children and adolescents is still limited, and new studies on the topic should be developed to better understand the influence of these variables on $\mathrm{VO}_{\text {2peak }}$ prediction.

This study has some limitations for analysis that should be listed, such as lack of information on sample characteristics, adiposity level, level of physical activity and sedentary behavior; especially related to correlation analyses for samples adjusted by gender. These limitations have turned the identification of the best predictive equation for different groups of children and adolescents into a challenge.

Therefore, future research should be able to provide more information on the sample, such as ethnicity, length of time with sedentary behavior, physical activity level, aspects of body composition and stage of sexual maturation, as well as to promote correlations with CRF. Thus, doubts about the association between these variables and $\mathrm{VO}_{2 \text { peak }}$ prediction can be better understood, allowing more accurate equations to be elaborated. It is also important that further research be conducted to verify the reproducibility of the equations proposed by Ruiz, ${ }^{17}$ Barnett (a), ${ }^{31}$ Matsuzaka (a) ${ }^{23}$ and Matsuzaka (b), ${ }^{23}$ identified in this review as promising but poorly explored in studies. These should be tested for both children and adolescents with different nutritional status, as well as gender-specific variations.

In the present study, we were able to point out the equations with better validity of $\mathrm{VO}_{2 \text { peak }}$ prediction for children and adolescents, as well as to identify aspects that hindered a more satisfactory analysis to elect a definitive equation. The suggestions presented in this review contribute to a more accurate elaboration and description of future studies, which contributes to the expansion of the scientific and practical knowledge about predictive equations for $\mathrm{VO}_{\text {2peak }}$ in children and adolescents.

In conclusion, our findings suggest that using more than one sample feature in equations tends to exert higher association values between predicted and measured $\mathrm{VO}_{2 \text { peak }}$. Matsuzaka's equation (a), in this sense, tends to have the strongest level of evidence with greater precision of estimation in children and adolescents. Although not explored in prediction equations, body fat percentage and sexual maturation stage are shown to have relevant associations with CRF in children and adolescents and further analyses of these variables in other equations are encouraged. However, new research should be conducted to evaluate the reproducibility of equations considered by this review as promising, as well as to improve the understanding about the relationship between anthropometric variables, body composition components and sexual maturation stages with $\mathrm{VO}_{\text {2peak }}$ prediction in children and adolescents.

\section{Funding}

Productivity grant, National Council for Scientific and Technological Development (CNPq), Department of Science and Technology (Decit/MS), Araucária Foundation and the State Health Secretariat of Paraná (SESA-PR).

\section{Conflict of interests}

The authors declare no conflict of interests.

\section{REFERENCES}

1. Ruiz JR, Huybrechts I, Cuenca-García M, Artero EG, Labayen I, Meirhaeghe A, et al. Cardiorespiratory fitness and ideal cardiovascular health in European adolescents. Heart. 2015;101:766-73.

2. Hamlin MJ, Fraser M, Lizamore CA, Draper $N$, Shearman $J P$, Kimber NE. Measurement of cardiorespiratory fitness in children from two commonly used field tests after accounting for body fatness and maturity. J Hum Kinet. 2014; 40:83-92.

3. Pozuelo-Carrascosa DP, García-Hermoso A, Álvarez-Bueno C, Sánchez-López M, Martínez-Vizcaino V. Effectiveness of school-based physical activity programmes on cardiorespiratory fitness in children: a meta-analysis of randomised controlled trials. $\mathrm{Br} J$ Sports Med. 2018;52:1234-40.

4. Victo ER, Ferrari GL, Silva Junior JP, Araújo TL, Matsudo VK. Indicadores de estilo de vida e aptidão cardiorrespiratória de adolescentes. Rev Paul Pediatr. 2017;35:61-8.
5. Lang JJ, Belanger K, Poitras V, Janssen I, Tomkinson GR, Tremblay MS. Systematic review of the relationship between $20 \mathrm{~m}$ shuttle run performance and health indicators among children and youth. J Sci Med Sport. 2018;21:383-97.

6. Tomkinson GR, Lang JJ, Tremblay MS, Dale M, LeBlanc AG, Belanger $\mathrm{K}$, et al. International normative 20 m shuttle run values from 1142026 children and youth representing 50 countries. Br J Sports Med. 2016;51:1545-54.

7. Assumpção MS, Ribeiro JD, Wamosy RM, Figueiredo FC, Parazzi PL, Schivinski Cl. Impulse oscillometry and obesity in children. J Pediatr (Rio J). 2018;94:419-424.

8. Hansen D, Hens W, Peeters S, Wittebrood C, Van Ussel S, Verleyen D, et al. Physical therapy as treatment for childhood obesity in primary health care: clinical recommendation from AXXON (Belgian Physical Therapy Association). Phys Ther. 2016;96:850-64.

9. Arena R, Cahalin LP. Evaluation of cardiorespiratory fitness and respiratory muscle function in the obese population. Prog Cardiovasc Dis. 2014;56:457-64. 
10. Lambrick D, Jakeman J, Grigg R, Kaufmann S, Faulkner J. The efficacy of a discontinuous graded exercise test in measuring peak oxygen uptake in children aged 8 to 10 years. Biol Sport. 2017;34:57-61.

11. Mayorga-Vega D, Aguilar-Soto P, Viciana J. Criterionrelated validity of the 20 -m shuttle run test for estimating cardiorespiratory fitness: A meta-analysis. J Sports Sci Med. 2015;14:536-47.

12. Pescatello LS, Arena R, Riebe D, editors. ACSM's guidelines for exercise testing and prescription. $9^{\text {th }}$ edition. Philadelphia: Wolters Kluwer/Lippincott Williams \& Wilkins; 2014.

13. Mora-Gonzalez J, Cadenas-Sanchez C, Martinez-Tellez B, Sanchez-Delgado G, Ruiz JR, Léger L, et al. Estimating VO2max in children aged 5-6 years through the preschooladapted 20-m shuttle-run test (PREFIT). Eur J Appl Physiol. 2017;117:2295-307.

14. Léger L, Lambert J, Goulet A, Rowan C, Dinelle Y. Aerobic capacity of 6 to 17-year-old Quebecois - 20 meter shuttle run test with 1 minute stages. Can J Appl Sport Sci. 1984;9:64-9.

15. Ruiz JR, Silva G, Oliveira N, Ribeiro JC, Oliveira JF, Mota J. Criterion-related validity of the $20-\mathrm{m}$ shuttle run test in youths aged 13-19 years. J Sports Sci. 2009;27:899-906.

16. Saint-Maurice PF, Welk GJ, Finn KJ, Kaj M. Cross-validation of a PACER prediction equation for assessing aerobic capacity in Hungarian youth. Res Q Exerc Sport. 2015;86:S66-73.

17. Ruiz JR, Ramirez-Lechuga J, Ortega FB, Castro-Piñero J, Benitez JM, Arauzo-Azofra A, et al. Artificial neural network-based equation for estimating VO2max from the $20 \mathrm{~m}$ shuttle run test in adolescents. Artif Intell Med. 2008;44:233-45.

18. Mahar MT, Guerieri AM, Hanna MS, Kemble CD. Estimation of Aerobic Fitness from 20-m Multistage Shuttle Run Test Performance. Am J Prev Med. 2011;41:S117-23.

19. Batista MB, Romanzini CL, Castro-Piñero J, Ronque ER. Validity of field tests to estimate cardiorespiratory fitness in children and adolescents: a systematic review. Rev Paul Pediatr. 2017;35:222-33.

20. Moher D, Liberati A, Tetzlaff J, Altman DG, PRISMA Group. Preferred reporting items for systematic reviews and meta-analyses: the PRISMA statement. PLoS Med. 2009;6:e1000097.

21. Castro-Piñero J, Artero EG, España-Romero V, Ortega FB, Sjöström M, Suni J, et al. Criterion-related validity of fieldbased fitness tests in youth: a systematic review. $\mathrm{B} r \mathrm{~J}$ Sports Med. 2010;44:934-43.

22. Suminski RR, Ryan ND, Poston CS, Jackson AS. Measuring aerobic fitness of hispanic youth 10 to 12 years of age. Int J Sports Med. 2004;25:61-7.

23. Matsuzaka A, Takahashi Y, Yamazoe M, Kumakura N, Ikeda A, Wilk B, et al. Validity of the multistage 20-M shuttle-run test for japanese children, adolescents, and adults. Pediatr Exerc Sci. 2004;16:113-25.

24. Melo X, Santa-Clara H, Almeida JP, Carnero EA, Sardinha LB, Bruno PM, et al. Comparing several equations that predict peak $\mathrm{VO}_{2}$ using the $20-\mathrm{m}$ multistage-shuttle run-test in 8-10-year-old children. Eur J Appl Physiol. 2011;111:839-49.
25. Silva G, Oliveira NL, Aires L, Mota J, Oliveira J, Ribeiro JC. Calculation and validation of models for estimating VO2max from the 20-m shuttle run test in children and adolescents. Arch Exerc Health Dis. 2012;3:145-52.

26. Batista MB, Cyrino ES, Arruda M, Dourado AC, Coelho-E-Silva MJ, Ohara $D$, et al. Validity of equations for estimating VO2 peak from the 20-m shuttle run test in adolescents aged 11-13 years. J Strength Cond Res. 2013;27:2774-81.

27. Burns RD, Hannon JC, Brusseau TA, Eisenman PA, SaintMaurice PF, Welk GJ, et al. Cross-validation of aerobic capacity prediction models in adolescents. Pediatr Exerc Sci. 2015;27:404-11.

28. Ernesto C, Silva FM, Pereira LA, Melo GF. Cross validation of different equations to predict aerobic fitness by the shuttle run 20 meters test in Brazilian students. J Exerc Physiol Online. 2015;18:46-55.

29. Léger LA, Mercier D, Gadoury C, Lambert J. The multistage 20 metre shuttle run test for aerobic fitness. J Sports Sci. 1988;6:93-101.

30. Liu NY, Plowman SA, Looney MA. The reliability and validity of the 20-meter shuttle test in American students 12 to 15 years old. Res Q Exerc Sport. 1992;63:360-5.

31. Barnett A, Chan LY, Bruce LC. A preliminary study of the 20-m multistage shuttle run as a predictor of peak VO2 in Hong Kong Chinese students. Pediatr Exerc Sci. 1993;5:42-50.

32. Pitetti KH, Fernhall B, Figoni S. Comparing two regression formulas that predict VO 2peak using the 20 -m shuttle run for children and adolescents. Pediatr Exerc Sci. 2002;14:125-34.

33. Mahar MT, Welk GJ, Rowe DA, Crotts DJ, Mclver KL. Development and validation of a regression model to estimate $\mathrm{VO}_{2}$ peak From PACER 20-m shuttle run performance. J Phys Act Health. 2006;3:34-46.

34. Boiarskaia EA, Boscolo MS, Zhu W, Mahar MT. Cross-Validation of an Equating Method Linking Aerobic FITNESSGRAM ${ }^{\circledR}$ Field Tests. Am J Prev Med. 2011;41:S124-30.

35. Fernhall B, Pitetti KH, Vukovich MD, Stubbs $N$, Hensen $T$, Winnick JP, et al. Validation of cardiovascular fitness field tests in children with mental retardation. Am J Ment Retard. 1998;102:602-12.

36. Quinart S, Mougin F, Simon-Rigaud ML, Nicolet-Guénat M, Nègre V, Regnard J. Evaluation of cardiorespiratory fitness using three field tests in obese adolescents: validity, sensitivity and prediction of peak VO2. J Sci Med Sport. 2014;17:521-5.

37. Pienaar C, Coetzee B, Monyeki AM. The use of anthropometric measurements and the influence of demographic factors on the prediction of in a cohort of adolescents: the PAHL study. Ann Hum Biol. 2015;42:135-42.

38. Saint-Maurice PF, Welk GJ, Laurson KR, Brown DD. Measurement agreement between estimates of aerobic fitness in youth: The impact of body mass index. Res Q Exerc Sport. 2014;85:59-67.

39. Lopes L, Santos R, Moreira C, Pereira B, Lopes VP. Sensitivity and specificity of different measures of adiposity to distinguish between low/high motor coordination. J Pediatr (Rio J). 2015;91:44-51. 
40. Ronque VE, Cyrino ES, Mortatti AL, Moreira A, Avelar A, Carvalho FO, et al. Relationship between cardiorespiratory fitness and indicators of body adiposity in adolescents. Rev Paul Pediatr. 2010;28:296-302.

41. Borfe L, Rech DC, Benelli TE, Paiva DN, Pohl HH, Burgos MS. Association between childhood obesity and cardiorespiratory fitness: a systematic review. Rev Bras Promoç Saúde. 2017;30:118-24.

42. Minatto G, Ribeiro RR, Achour Junior A, Santos KD. Influence of age, sexual maturation, anthropometric variables and body composition on flexibility. Rev Bras Cineantropom Desempenho Hum. 2010;12:151-8.
43. Soares NM, Silva RJ, Melo EV, Oliveira AC. Influence of sexual maturation on cardiorespiratory fitness in school children. Rev Bras Cineantropom Desempenho Hum. 2014;16:223-32.

44. Minatto G, Petroski EL, Silva DA. Body fat, muscular and cardiorespiratory fitness according to sexual maturation among Brazilian adolescents from a town of German colonization. Rev Paul Pediatr. 2013;31:189-97.

45. Aguilar MM, Vergara FA, Velásquez EJ, Marina R, GarcíaHermoso A. Screen time impairs the relationship between physical fitness and academic attainment in children TT. J Pediatr (Rio J). 2015;91:339-45. 